\title{
Educational Relevance of the Arts in a Technocratic World
}

Carla J. Glen

Simon Fraser University and University of Northern British Columbia

\section{Author Note}

Correspondence concerning this article should be addressed to Carla J. Glen, 5544 Kleanza

Drive, Terrace, British Columbia, V8G 0A7. E-mail: carla.glen@gmail.com

\begin{abstract}
Today, it is important to acknowledge our investment in the technologized visual culture world, but at the same time within that investment, allow for active participation in forms that press for engagement and reflection. Theorized through phenomenology, embodiment, and performative inquiry, Arts' Educational Relevance in a Technocratic World presents an awakening of space moments of possibilities through active and interactive participation in installation art forms that press for participatory inquiry, engagement, and reflection with our close entanglement with the technologically driven visual culture world, the world in which we dwell, in relationship to our selves and others.
\end{abstract}

Keywords: visual culture; installation art; phenomenology; enactivism; performative inquiry 


\section{Educational Relevance of the Arts in a Technocratic World}

\section{"There cannot be an art world without theory, for the art world is logically dependent upon theory...An art theory can detach objects from the real world and make them part of a different world, an art world, a world of interpreted things.” (Danto, 1981, p. 135)}

The art world of which Danto speaks is a constructed visual world; therefore, it is provisional, contingent, and always, then, open to critique, expansion, and revision. In the multimedia environment today, mechanical and electronic images, text, and sound are an almost constant presence. The various mass media ${ }^{\underline{1}}$ (e.g. television, radio, newspapers, magazines, cinema, Internet, World Wide Web, digital multimedia) often work in unison to generate specific dominant or popular representations of events, people, and places, whether these events are fictional, actual, or somewhere in-between. These media are pervasive in much of a person's

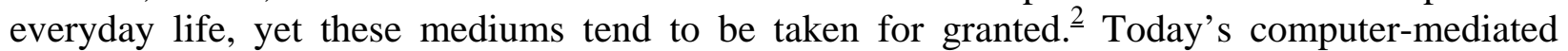
visual culture is shrouded in a cyberspace that renders bodies immaterial, or one in which bodies that are marked, often violently, according to racial, sexual, and social differences which create a new intensity of a dis-connected world (Merleau-Ponty, 2006, pp. 240-41). ${ }^{3}$ In the course of a day, this dis-connection can consist of the next round of Canadian soldiers killed in Afghanistan; Iran's 2009 election deemed as democratic by Ahmadinejad; Bashir genocide charges, ethnic riots in Urumqi in western China (also streamed on YouTube); the pandemic Swine flu viral attacks; the bombings of EnCana's natural gas pipeline in northern British Columbia (B.C.); the YouTube video of the racial attack of three young White men beating up a young Black man in Courtenay, B.C.; and further, photos of the recent gang rape of a 16-year-old girl in Pitt Meadows, B.C., displayed on Internet social media sites; and finally, of course, we can't forget the death and memorial spectacle of popular culture icon, Michael Jackson. All contribute to the spectacular wired events to which consumers of information and entertainment have become accustomed. This wiring connects and disconnects the mass media consumer simultaneously, rendering him or her both psycho-technologically immediate to events and geopolitically removed from them. This simultaneous wiring underpins the effects of spectacle to which Guy Debord (1967) refers in The Society of Spectacle. ${ }^{4}$

Has the technological, media-wired society unconditionally accepted a blending of the boundaries between news and fiction, between entertainment and information in the daily ration of information, news, and entertainment? When the Gulf War was televised live, I was repelled by the politics (working in television at the time), but at the same time riveted by the spectacular images of missiles flying through the darkness of the night and exploding like fireworks - a smart bomb and I as spectator were locked in as one. I was able to see what the bomb was going to destroy, and what it did destroy, from the safety of my television studio in British Columbia, Canada. Further, when 9/11 occurred, I watched the unfolding of the repetitive (looped) images and events again and again from my studio. I remember about 9 hours of looped video over the course of the day - the spectacle blended with numbing horror.

Watching these mediated events created a new intensity derived from the televised "live" event. I was haunted by the paradox of disgust undercut by fascination of the mechanics of war and terrorism; a splitting of the body image in the ecstasy of dispersal rescued by armour (military troupes and firefighters). What happens to a technologically driven society when its members are suspended between an obscene proximity and a spectacular separation? Might it be possible that people begin to function on autopilot-moving through the world passively, seeking diversions with partial recognitions punctuated with complete abhorrence? How do 
members of a technologically driven society come to critically distance themselves in order to recognize and understand their role as active participants in the world, individually and collectively questioning what is taking place in a day-to-day existence so inundated with information, images, news, and the spectacular, 24/7?

“You've been living in a dream world, Neo.” (Morpheus, The Matrix, 1999)

Too far, too close: the imperative of proper perspective. Have people today been overshadowed by global events, mediated through violent images and fear, and punctuated with the spectacular in the technologically driven world? Has mass media consumerism rendered people complacent and unaccustomed to arousing deep echoes daily from within? To judge or to decide: analogy between pictorial and spatial construct is reflected, filtered, and projected as images over and over again that no longer connect us with our sensibility, and thus keep us in an intellectual stupor. Each person appears to be in the world, but only through representations of his or her self through the other: the other being visual culture..$^{\frac{5}{}}$ According to theatre practitioner, Antonin Artaud (1970), our sensibility has reached the point where we surely need art forms that wake us up heart and nerves (p. 64). ${ }^{-}$How are we to respond, to regain agency, and speak to our own understandings of what matters?

\section{"These people are the actors. There is no possibility of escape. In fact the spectators have no choice. They are obliged violently to participate."?}

The potentiality of installation art as witnessed in Graciela Carnevale's work is that it offers spectator/participants the opportunity to actively engage through embodiment, and question (visual) culture's role in our everyday relationships as lived. Art forms that possess exultant feeling and embodied stimulation, by allowing spectators to physically enter the work in a sitespecific space, have been redirected and expanded from the borders of theatre, conceptual art, and performance art, so as to comprise the installation art form as reinvigorating it/self. The ultimate concerns are directed towards the spectator/participant's presence. Installation art, through performative inquiry, evokes a desire to activate the individual from a passive mass media consumer, and to induce critical dialogue towards the environments in which individuals find themselves daily. The centre is the individual, the spectator/participant, for which everything is intended.

Philosopher, Alfred Schutz (1967) spoke of wide-awakeness as being in the world, as actively engaging and reflecting critically and passionately with respect to our daily undertakings in life:

[W]ide-awakeness...full attention to life and its requirements. [The fully engaged and interested self] lives within its acts and its attention and is exclusively directed to carrying its project into effect, to executing its plan. This attention is an active, not a passive one. Passive attention is the opposite to full awareness.(p. 213) ${ }^{\underline{8}}$

A possible marker of a way forward — of being in the world ${ }^{9}$ as a wide-awake, active participant in/with the visual-is offered through relational art form, which takes its theoretical foundation from the realm of human interactions and social context, as with performative inquiry, (the creative action-interaction of inquiry and learning), and through the active engagement of installation art. The possibility of a relational installation art form that draws from human interactions and relationships in its social context has the potential of creating social exchange and interaction with the installation artwork for the spectator as participant inside the 
installation. These elements of interactivity, $\frac{10}{}$ reception, and production, then, become the dissolution of any distinction between spectator, participant, and spectacle, reception, and production. The affect on the body is presented in the reflexive experience through actions. What makes the interactivity interesting is that by feeling the performing act, the action becomes articulated; wide-awakeness occurs. What was once an undifferentiated experience, such as passively ${ }^{11}$ looking at artwork on a gallery wall, or watching the 9/11 events unfold over and over again on television, or some sort of pleasurable experience, becomes differentiated in the performative act. The first action can be an enjoyable (or not), predictable, passive discovery of a clear image; however, the second action, of actively inquiring and engaging within the installation form, feels risky, erratic, unpredictable, and senseless, like groping for the image and dragging it out of darkness - then losing it again: as if getting stuck. Hence, by performing the act, discovery of the body is heightened-as well as the world around, and the relationship to the world around - the body's presence in the world is heightened. This is also what Maxine Greene (1978b) articulates when she positions the significance of being a fully active engager through Schutz's notion of wide-awakeness, where educating through the arts is concerned. For Greene, engaging through the educational involvement of the arts has the potential for provoking precisely Schutz's notion of active reflectiveness. Greene (1978b) asserts:

We need to devise ways of integrating arts and humanities into what we teach at all levels of the educational enterprise: we need to do so consciously, with a clear perception of what it means to enable people to pay, from their own distinctive vantage points, "full attention to life.” (p. 163)

For Greene, it is the distinctiveness of the arts that allows for communicating in such a way that the participator would become aware of their "personal mode of existence" (Kierkegaard, 1962, pp. 44-53) $)^{12}$ as to what arts should be about. A relational art encounter, as in installation art, allows for a space of openness that inaugurates dialogue. These relational spaces incorporating human-to-human encounters and experiences try to reawaken the constraints of the ideology of mass media communication; in a sense, relational spaces may become spaces of conviviality. This is where and how learning should be engaged. Interestingly though, with the speed of audiovisual technological change and a reified ${ }^{13}$ (constructed) spectacle of culture that today confronts telecommunications, entertainment, educational media, and the individual within the audiovisual technological world, the interconnected relationship between the body and technology appear to be gradually morphing with the appearance of new forms of the communicating formats, such as Facebook, Flicker, Twitter, and virtual reality technology. Technology becomes an extension of our bodies that can blunt the body's capacity to feel for one another. It is easier to simply let a message be sent to a blog, Facebook, or Twitter website rather than have the direct communication (with the e.g., friend or colleague) face-to-face at a coffee shop or at the office.

The communication technology of cell phones, iPhones, Facebook, Twitter, YouTube, and even Flickr have diverted the immediacy of face-to-face communication with others. It is so easy today to launch multiple images of "vehicle surfing” (YouTube, 2009) for the thrill of mass communicating the "visual buzz" of the event rather than it is to meet face-to-face and talk about the particular event that occurred. We have moved our bodies into the spectacle of mass communication with an indifference to consequences. Greene (1978a) speaks of moral action that demands choosing between alternatives, usually between two goods, not between bad and good, right or wrong (p.48). The difficulty today is finding ways to instill an empowerment to 
(young) people in order for them to internalize and incarnate the kinds of principles that will enable them to make such choices. The fast, easy, and accessible audio/video technology makes our bodies far more flexible, but in some ways much less responsive. Technology corporations recognize our senses for swiftness and multiplicity, rather than depth, persistence, or intensity. Karl Marx (1998) considered that by turning even our senses into commodities, capitalism had plundered us of our bodies. In Marx's (1998) view, we would need a considerable political transformation in order to come to our senses. According to Marx, social conditions determine character, both directly, through their effect on our individual powers and needs, and indirectly, through the creation of interests which we strive to satisfy.

\section{“If we are to change our world view, images have to change." (Hockney, 2009)}

Visual culture can appropriate production, religion, politics, art, morality, literature, family, state, science, and so forth, as a form of visual embodiment and reflect it back on us, the spectator and consumer, in the capacity of work, currency, clothing, shelter, family, foods, gods, moral codes, laws, art, and so on, that all become what we have become, or what we want to become. We are always striving to "fit in," to find our place, our space, in what visual culture presents as the "norm." We are constantly re-presented with visual culture influences as to what we want, what we are capable of, what sacrifices we need to make, and what satisfies us. Material production has become the necessary character of our daily tasks, and the amount of time devoted to achieving our tasks is evident in the areas of our lives where our power to achieve and accumulate is most evident. Underpinning visual culture is human culture (Hall, 1997) comprised of knowledge, beliefs, arts, morals, laws, customs, language, and any other capabilities and habits acquired by a person as a member of society (Tylor, 1903). ${ }^{15}$ Culture is a system of building identity. It is how people survive and flourish, produce and exchange meanings, and give and take meaning between members of a group or society. Stuart Hall (1997) states: "It is the participants in a culture who give meaning to people, objects, and events...It is by our use of things, and what we say, think and feel about them-how we represent them-that we give them meaning” (p. 3). Culture, through its shared practices is how meaning is made-it is a variable and changing process. People are materially programmed towards culture because meaning, symbolism, interpretation, and so on are essential to what and who they are; this is why people access the visual culture of which they are an active part. The preoccupation of imagemaking techniques in visual culture keeps reminding us of our selves and how we make sense of things in our everyday lives. Through the appropriation of congruent images from visual culture, installation art offers a mutual and reciprocal point of departure for the individual to recognize other perspectives, acknowledge them, transform them, and be ready to be transformed by them. Perceptually guided performative inquiry in installation art has the potentiality to move towards a predominant form of expression in today's world, as we know it, with global character, desire for sensory overload, and demand for non-elitist practices.

Merleau-Ponty’s (1962) phenomenological assumption of each person being a complex fabric of relations inextricably linked with everything else situates the human body and the world as linked through lived experience, as Schutz (1967) asserts with "being in the world through wide-awakeness” ( p. 213). The enactivists, such as Francisco Varela and Humberto Maturana (1987) argue that the enactment of a world and a mind by an individual knower is not simply enacted as an observer of the world, but the individual is embedded in the world and is shaped both cognitively and as a whole physical organism by interactions with the world (p. 172). The practice of installation art, underpinned by the theory of phenomenology, embodiment and 
performative inquiry, allows spaces for possibilities to challenge the limits of our perceptions of spectacle representation of the everyday. Through active, physical engagement, individuals are given opportunities to discuss their place or space in the world, to challenge the forces that appear to dominate them, and to interpret the experiences they are having daily with the visual culture. Only as people learn to make sense of what is happening by face-to-face communication with others, manipulation of objects, and navigation through various information spaces through installation art forms can each person begin to have agency and feel autonomous.

To find ways of educating by challenging the visual culture spectacle representation of the everyday requires taking a position, by critically inquiring and engaging with what is taken for granted. The Brechtian epic model, for example, of defamiliarising (Brecht, 1964/1993) ${ }^{\frac{16}{16}}$ can be used to raise consciousness of critical thinking. ${ }^{17}$ The spectacle distance becomes an important starting point of engagement in understanding why we-as consumers, producers, and managers of personal and collective stories, products, services, and images - willingly accept a life scripted by an other who appears to be a better producer, manager, storyteller and performer of our individual and collective stories. If culture in the context of technology becomes something we "do" then it's by awakening our sensibilities through performative inquiry that defines how we do it and how the "doing" feels. The body becomes the awakened interface ${ }^{18}$ of inquiry and engagement in the installation art form.

\section{“If I... ask if all be right, from mirror after mirror, no vanity's displayed: I'm looking for the face I had before the world was made." (Yeats, 2003, p. 142)}

Educating by challenging the moral implications is presented in Greene's (1978a) example of young people pressed to take a moment and recall the feelings they had when they first, for example, smoked marijuana: the nervousness of losing touch with themselves, the dread about what may happen later and so forth (p. 46). Finding significant ways of educating to a sensitivity and potency becomes the wide-awakeness for the educator, as well as for the individuals. Drawing from Greene, then, it is through the significance of considering the implications of doing the act (e.g., the gang-rape photos displayed on social media sites, the vehicle surfing spectacle for play on YouTube), and confronting his or her reluctance to breaking the law, deciding to possibly back away - that the agency, the autonomy, and the freedom allowed in a space of active participatory engagement presents possibilities for individuals to assess the situation and choose one course of action over another. Actively involved people in installation art forms have the potentiality to question and begin to understand implications of visual spectacle actions and be on their way to becoming moral agents through the act of performative inquiry of visual culture. The installation art form (by its appropriation of congruent images of visual culture) presents space-moments of possibilities for individuals to develop the sense of moral agency to speak to moments of recognition, disruption, and interruption that arise from daily life and visual culture through active inquiry and engagement in the installation.

If we believe that we are inextricably linked through a complex fabric of relations in a lived world (Merleau-Ponty, 1967), then active engagement within a predominately highly technologised visual culture today is crucial, because we must come to recognize and incorporate communication strategies for understanding visual culture and our relation to it in the everyday. The interrelationship between spectator/participant and installation art form and the (wider) world becomes a matter of embodied perception because what the spectator/participant perceives is necessarily bound on being at any moment physically present within a matrix of encounters that determine how and what will be perceived (Merleau-Ponty, 1967). Embodied action 
emphasizes a negotiation of an in-between space of moments of possibilities of understanding our relationship with and in visual culture. The body engages first with experiencing the visual culture before reflection and theorizing. Active engagement through an installation art form through the perceptually guided and embodied action of performative inquiry allows for possibilities to produce a specific place of sociability, activation, authorship, and community. The participant actively engages and challenges dominant codes of visual culture, situating and validating the individual as a site of understanding (a site of autonomy - of freedom, of action) through the face-to-face immersion in the installation and ultimately in the world.

\section{“Caution: Objects in mirror are closer than they appear." $\underline{19}$}

French philosopher Jean Baudrillard (1988) described the late twentieth century as a period during which images were more real than real. Baudrillard (1988) writes:

[I]f they [images] fascinate us so much it is not because they are sites of the production of meaning and representation this would not be new - it is on the contrary because they are sites of the disappearance of meaning and representation, sites in which we are caught quite apart from any judgement of reality. (p. 29)

Now in the $21^{\text {st }}$ century, we have passed from an era in which reproduction and representation are the most crucial aspects of how we come to understand the visual culture. Wide-awakeness is needed to affect contemporary thought and particularly the moral responsibility and commitment today in educating and learning through the arts as we strive to live out our daily lives in a mechanical round of habitual activities inundated with images technologically driven from visual culture. For Baudrillard, simulation is the new image paradigm that replaces representation. We live in a culture dominated by duel dual computer screens, high-definition television sets, iPods, iPhones, Blackberries, the Internet and World Wide Web; a culture that has become the paradigm for global visual culture practices ruled by the simulacra of fast-paced,virtual media images. ${ }^{20}$ Unlike representations, which make reference to something real, simulacra stands on its own without requiring recourse to real objects or worlds elsewhere.

Within Baudrillard's (1988) terms, the "hyperreal" overtakes the real, and the simulacra rises, partly through new media technology as the new forms of our postmodern existence today. This is a static engagement with the visual culture; the engagement with representations and the hyperreality are replacements for the immediacy of what Greene (1978) offers as an example of paradoxes in arts education. For Greene (1978a), any transcendent encounters with art objects establish a kind of “clearing” (p. 2) for critical transactions-in other words, in understanding our interrelationship with visual culture, a shock of awareness to which arts encounters give rise that establishes and evokes an illumination of invisibilities (Merleau-Ponty, 1968, p. 320) $\frac{21}{1}$ and floods spaces of resistance (a tension between the present and the future, a present loaded with commitments and consequences), which leaves individuals less immersed in the everyday and more compelled to wonder and to question the everyday.

In our fast-paced, technologically-driven world where our engagement with spectacle representations of the everyday-the passive social relationship between people mediated by images and separation (Debord, 1967, pp. 33 \& 143) determine and overtake our reality-life no longer is lived directly and actively (Best \& Kellner, 1997, p. 88). We passively consume commodity spectacles and services without active and creative involvement. The practice of installation art drawing from the theory of phenomenology, embodiment, and performative 
inquiry allows a clearing, a space of creative learning, of making meaning, to challenge the limits of our perceptions of spectacle representation of the everyday. The active engagement of people in an installation art form (which appropriates and remediates ${ }^{22}$ congruent images from visual culture) creates an opportunity to speak to wide-awakeness: moments of recognition, disruption, and interruption for the individual through performative inquiry. If we believe spectacle denotes a mode of passivity and subjugation that arrests thought and prevents an awakening of critical consciousness (Debord, p. 138) then the aim of arts educating and learning through installation art forms is to draw attention to the knowledge we are constantly enacting, but is relegated to the background of conscious experience of confining ourselves to a "main text" of which Michel Foucault (1984) describes as being conceived as the ordinary, the everyday, a normalization of what is worthy, what is respectable (p. 197). ${ }^{23}$ The active act of performative inquiry becomes an important point of departure for intervening and communicating beyond the boundaries of a main text and learning through active creative engagement, as the act itself is understanding (Fels, 1999).

At present, we live in a confusing world. The power of the technologically driven visual culture in our everyday lives is a condition with which we need to come to terms rather than to try and escape. We must freely acknowledge our investment in this visual culture, but at the same time within that involvement, allow for space-moments of possibilities through active and interactive participation in installation art forms that press for participatory inquiry, engagement, and reflection in a number of ways:

- $\quad$ in our close entanglement with technology (visual culture) and its practices;

- in the deconstruction of the idea of one complete story or one complete site of performance allowing for multiple assemblages of sites and/or stories to emerge;

- on a beginning of a shift, to move away from the mono-linearity of conventional theatre as passive spectator resulting in a decentring of inscribing practices where the body becomes the site of text in order to engage the spectacle of mechanical and electronic devices in technology;

- in creative inquiry through an installation art form to challenge the dialectic of technology's (visual culture's) intervention in the body and the body's intervention in technology (visual culture); and

- to explore and critique technologies (visual culture's) implications in order to evolve an ethics of embodied technological/visual culture intervention.

A singular vision of the future of our everyday is indeterminate. However, we must come to understand the art world and its interrelationship to our everyday lives. Installation art forms that create space-moments of possibilities, of active inquiry, engagement, and communication with others, become a form of endless possibilities of meaningful encounters by overcoming the perception of spectacle in visual culture for which attention is made attentive to everything other than itself. The invisible becomes visible through dialogue and participatory inquiry, creating possibilities for arts-based educating and learning through projects that incorporate theories from phenomenology, embodiment, and performative inquiry. Arts-based projects in this capacity have the potentiality to consciously awaken our autonomy as situated $\underline{24}$ persons, individually and collectively. It is through our choices, by understanding the variety of perspectives and the incompleteness of our selves in the visual world that merge when coming to understand our 
place in and with the visual culture and the world. These choices influence the changes we make to our selves in order to bring about the best future for tomorrow as educators, learners, and participants in our technologically driven global community.

Finally, Gilles Deleuze (1995a) addressed a notion of the relationship of politics to art through the reflection on the creation of people that seems to me to apply to the significance of the need for active participation, inquiry and the wide-awakeness of people dialoguing in, through, and around the installation art form: "When a people is created ['creates itself'], it does so through its own means, but in a way that rejoins something in art...or in such a way that art rejoins that which it lacks” (p. 174). Artists and artworks cannot themselves create a people, and everyday struggles cannot concern themselves directly with artist or artwork. Processes emerge that connect artist, artwork, and the citizenry. When individuals begin to take form (work together), or physically and actively inquire and engage, interactive processes emerge that connect artist, artwork and individuals. To actively inquire and critically engage by entering installation art forms from the vantage point of a wide-awake (Greene, 1978) individual in everyday life allows, then, endless confrontations for the possibilities of laying down a path in walking (Varela, 1987) with the art world, the worlds in which he or she dwells in relationship to self and others. 


\section{References}

[Archival images of Graciela Carnevale (1968) from the 2009 Project for the Experimental Art Series, Rosario.] Retrieved from http://centrefortheaestheticrevolution.blogspot.com/2009/06/graciela-car... and http://www.tate.org.uk/tateetc/issue16/futurism1.htm

Artaud, A. (1970). The theatre and its double (V. Corti, Trans.). London, England: John Calder Publishing.

Baudrillard, J. (1988). The evil demon of images (P. Patton \& P. Foss, Eds.). Sydney, Australia: University of Sydney.

Best, S., \& Kellner, D. (1997). The postmodern turn. New York, NY: The Guildford Press.

Brecht, B. (1993). Brecht on theatre: The development of an aesthetic (J. Willett, Ed. \& Trans.). London, England: Methuen Drama.

Danto, A. (1981). The transfiguration of the commonplace: A philosophy of art. Cambridge, MA: Harvard University Press.

Debord, G. (1995a). The Society of Spectacle (D. Nicholson-Smith, Trans.). New York, NY: Zone Books.

Deleuze, G. (1995b). Negotiations (M. Jougin, Trans.). New York, NY: Columbia University Press.

Duchamp, M. (2008). Artwork retrieved from http://www.marcelduchamp.net/artworkspage.php

Fels, L. (1999). In the winds clothes dance on the line. (Unpublished doctoral dissertation). University of British Columbia, British Columbia, Canada.

Foucault, M. (1984). The means of correct training. In P. Rabinow (Ed.), The Foucault Reader. New York, New York: Pantheon Press.

Glen, C.J. (2006). Aristotle's catharsis: The catalyst for Brecht's epic theatre. Unpublished manuscript, Department of Education, Simon Fraser University, Burnaby, British Columbia, Canada.

Greene, M. (1978a). Towards wide-awakeness: An argument for the arts and humanities in education. In Landscapes of learning (pp. 161-167). New York, NY: Columbia University Teachers College Press.

Greene, M. (1978b). Wide-Awakeness and the moral life. In Landscapes of learning (pp. 42-52). New York, NY: Columbia University Teachers College Press.

Hall, S. (1997). Representation: Cultural representation and signifying practices. London, England: Sage Publications Limited.

Hockney, D. Great Britain Pop artist retrieved from http://www.ibiblio.org/wm/paint/auth/hockney/

Kierkegaard, S. (1962). Point of view for my work as an author (B. Nelson, Ed.). New York, NY: Torchbooks.

Marx, K., \& Engels, F. (1998). The communist manifesto (D. McLellan, Ed.). New York, NY: Oxford University Press. 
Maturana, H., \& Varela, F.J. (1987). The Tree of Knowledge: The Biological Roots of Human Understanding. Boston, MA: New Science Library.

Merleau-Ponty, M. (1968). The Visible and the Invisible (C. Lefort , Ed.; A. Lingis,Trans.). Evanston, IL: Northwestern University Press.

Merleau-Ponty, M. (2006). Phenomenology of Perception (C. Smith, Trans.). New York, NY: Routledge Classics.

Ollman, B. (1996). Alienation: Marx's conception of man in capitalist society ( $2^{\text {nd }}$ ed.). New York, NY: Cambridge University Press.

Schutz, A. (1967). The problem of social reality. In M. Natanson (Ed.), Collected papers (Vol. 1). The Hague, Belgium: Marinus Nijhoff Publishers.

Tylor, E.B. (1903). Primitive culture: researches into the development of mythology, philosophy, religion, art, and custom (1871). Retrieved from http://www.archive.org/stream/primitiveculture00tylogoogle\#page/n6/mode/2up

Varela, F.J. (1987). Laying down a path in walking. In W.I. Thompson (Ed.), GAIA: A way of knowing-political implications of the new biology (pp.48-64). Hudson, NY: Lindisarne Press.

Varela, F.J., Thompson, E., \& Rosch, E. (1991). The embodied mind, cognitive science and human experience. Cambridge MA: MIT Press.

Wachowski Brothers, The. (Writers and Directors). (1999). The matrix. United States: Warner Bros.

Yeats, W.B. (2003). Woman young and old. In P. Schwyzer \& S. Mealor (Eds.), Archipelagic identities: Literature and identity in the Atlantic archipelago, 1550-1800. Burlington, VT: Ashgate.

YouTube. (2009). Streaming video: Truck surfing. Retrieved from http://www.youtube.com/watch?v=7899CfQNTVI

\section{Endnotes}

1 Mass media is used to define those media that reach a large audience perceived of having shared interests.

$\underline{2}$ Some key media/technology scholars who are concerned with the impact of visual-technology include: M. McLuhan, W.J.T. Mitchell, F. Jameson, M. Hansen, N. Chomsky, M. Jay, N. Mirzoeff, J. Fiske, N.K. Hayles, D. Haraway, A. Jones.

3 Maurice Merleau-Ponty speaks of the body and the world as one through a lived experience. The dis-connected body and world here, is the dis-embodied world; we are unable to make meaning upon the world through relational interactions within the social context of the visual culture world.

${ }^{4}$ For Debord, spectacle is the representation as social relationship between people mediated by images that also creates a divisiveness between people. 
${ }^{5}$ Visual culture here is premised on the unprecedented importance of mediated imaging and visual technologies in contemporary society, and concerned with all kinds of visual information, its meanings, pleasures, and consumption.

${ }^{6}$ In The Theatre and its Double, Artaud speaks to theatre however any art form that arouses the participants to be connected, alive to their sensibilities in a fiery, magnetic manner.

7 Graciela Carnevale’s, Project for the Experimental Art Series, Rosario, 1968, was an erruption of politicized participatory practice that took a dramatic form in Argentina. The Experimental Art Cycle was a series of actions of Rosario, many of which worked on the audience as a privileged artistic material. Graciela Carnevale's project represents the most extreme example of this approach. In the years that followed, Carnevale, abandoned art for teaching. The work consisted of preparing a totally empty room. The participatory audience (who came together by chance) had been locked in this room without the audience 's awareness. Prisoners. The point is to allow people to enter but not leave. The audience members are the actors. The positive or negative outcome is determined by the audience members and what they will ultimately do to escape this locked room. This work is an act of aggression, and its intent is to provoke the spectator into awareness of the power with which violence is enacted in everyday life.

$\because$ Also see Maxine Greene's Landscapes of Learning, New York: Columbia Univ. Teacher's College Press, 1978, as she refers to Schutz's notion of wide-awakeness in educational terms.

9 Merleau-Ponty also discusses being in the world in phenomenological terms.

$\underline{10}$ Interactivity in art forms is not new. Marcel Duchamp's 1957 lecture on 'the creative act' became a starting point and a point of arrival, or in other words, the main theme that informed the artist's work. See http://iaaa.nl/cursusAA\&AI/duchamp.html

11 The term passive (i.e. passivity, passive encounters, passive spectator) used throughout this article, is premised on the understanding there is a concern in contemporary society, that we are mediated by images from our daily visual culture that become our dominant model of social life. I am attending to this concern through the performative inquiry lens in installation art. As cultural beings, we unconditionally accept and/or conform to what (visual) culture presents as the "norm" and thus, allow the spectacles of visual culture to subjugate us, not allowing us to be alert, to critically question or challenge what is presented to us through the various mediums used to transmit visual culture practices.

12 Greene in "Towards Wide-Awakeness," uses Kierkegaard’s assertion of civilisational malaise reflecting on he inability of civilization directed to material improvement-higher incomes, better diets, miracles of medicine and so forth - to satisfy the human spirit to underpin her argument for active participatory arts engagements in education in order for people to awaken to their freedom of communicating in a lived reality. For Greene (as with Kierkegaard) and the industrial age, then the technological age, there is a passive response to personalisation, automatisation, and routinisation of daily life.

$\underline{13}$ The reified (constructed) spectacle of culture corresponds to the moment in society where commodity completes social life. It is not that the relationship to commodities is plain to see, but commodities are now all that there is to see; the world we see is the constructed world of the commodity. See Debord's Society of Spectacle; Best's and Kellner's, The Postmodern Turn; Marx and Engels', The Communist Manifesto, and Ollman's, Alienation: Marx Conception of Man in Capitalist Society. 
$\underline{14}$ Culture (e.g., shared practices of a group, community, or society) according to the British cultural theorist Stuart Hall, is not so much a set of things (television shows or paintings) but moreso a set of processes or practices through which individuals and groups come together to make sense of those things.

15 Although E.B. Tylor (Primitive Culture: Researches into the Development of Mythology, Philosophy, Religion, Art, and Custom, 1871) was not aiming to propose a general theory of culture (his explanation was situated around the nature of religion), his theory has underpinned many North American anthropologists as refinements of Tylor's work.

$\underline{16}$ Brecht presents his strategy of alienation effect that presents situations that disrupts the participant by interrupting the narrative pressing the spectator to question what is taking place on stage through montage and juxtaposition. The spectator's identification with the protagonist is disrupted. Compelling the spectator to take up a position towards the action.

$\underline{17}$ Critical thinking in relation to dramatic representation according to Brecht first: must have a cognitive aspect to critical thinking: the participant must reach his or her own independently justified conclusions (the participant must be able to give an opinion through a process that provides independent justification for the conclusion reached); second: as a Marxist, Brecht observed that people around him (p. 133) took for granted certain basic precepts-that society is a meritocracy in which individuals rise and fall economically depending on how clever they are or how hard they work; adherence to capitalism and Fascism in the early to mid twentieth century Europe. Brecht wanted the people to question what they saw so they would be ready to go from theatre to their everyday lives to change their situation in society. See Carla Glen, “Aristotle’s Catharsis: The Catalyst for Brecht’s Epic Theatre,” unpublished paper, 2006.

${ }^{18}$ The interface is the point at which two or more systems or pieces of equipment are connected. The body becomes the interface of engagement through assemblages in an open and connectable linkage, or blurring of the boundaries between domains of ethnography, linguistics, society, politics, technology, and so on. The interface in this sense is detachable, reversible, and susceptible to constant modification; since each domain is tied to each other and always fusing back together through the site of the body.

$\underline{19}$ Taken from the side mirror on the passenger side of a motor vehicle.

$\underline{20}$ In the past few decades, we have begun to perfect art and science of creating virtual worlds and elaborate theme parks (i.e. Disneyland, Disneyworld). As a result, we can now take the realm of imagination and make it seem to come to life. Fiction begins to look like fact-the "house hippo" advertisement on television is a positive example to help children become better equipped at differentiating and understanding what is real and what is fiction.

${ }_{21}$ Merleau-Ponty speaks of the invisibility in The Visible and the Invisible where objects are not separate entities but are reciprocally intertwined and interdependent.

$\underline{22}$ The term remediatation means to refashion old media such as perspective painting, photography, film, and television in order to reuse it in another way presenting a new reflexive meaning.

$\underline{23}$ Foucault describes normalization as the power that imposes homogeneity that allows people to determine levels, to fix specialties, and to render the differences useful by fitting them one to another. 
24 A situated person is grounded in his or her sense-making and understanding of what it is to exist in the (visual culture) world. The situated person is far less likely to confuse abstractions with concreteness, formalized, and schematized reality with what is real. See Greene's, Towards Wide-Awakeness. 